\title{
What constitutes essential nursery habitat for a marine species? A case study of habitat form and function for queen conch
}

\author{
Allan W. Stoner* \\ Fisheries Behavioral Ecology Program, Alaska Fisheries Science Center, National Marine Fisheries Service, NOAA, \\ 2030 S. Marine Science Drive, Newport, Oregon 97365, USA
}

\begin{abstract}
There is increasing recognition that habitats should be managed as part of fisheries management. It is generally assumed that amount of suitable habitat is linked to production of demersal species and that maps of bottom type will provide the information needed to conserve essential habitats. In this review, a synthesis of nursery habitat is made for Strombus gigas (queen conch), a large, economically important gastropod in the Caribbean region. Juveniles occur on a variety of bottom types over their geographic range. In the Bahamas, nurseries occur in specific locations within large, beds of seagrass, while obvious characteristics of the benthic environment such as seagrass density, depth and sediment type are not good predictors of suitable habitat. Rather, nurseries persist where competent larvae are concentrated by tidal circulation and where settlement occurs selectively. Nursery locations provide for high juvenile growth resulting from macroalgal production not evident in maps of algal biomass, and they provide for low mortality compared with seemingly similar surroundings. Therefore, critical habitats for queen conch juveniles are determined by the intersection of habitat features and ecological processes that combine to yield high rates of recruitment and survivorship. While maps of bottom type are a good beginning for habitat management, they can be traps without good knowledge of ecological processes. A demersal species can occupy different substrata over its geographic range, different life stages often depend upon different bottom types, and specific locations can be more important than particular habitat forms. Habitat management must be designed to conserve habitat function and not just form. Implicit in the concept of 'essential habitat' is the fact that expendable habitat exists, and we need to prevent losses of working habitat because of inadequate protection, restoration or mitigation. Key nurseries may represent distinctive or even anomalous conditions.
\end{abstract}

KEY WORDS: Essential fish habitat · Habitat mapping · Habitat management · Seagrass · Recruitment · Strombus gigas Resale or republication not permitted without written consent of the publisher

\section{INTRODUCTION}

It is axiomatic that animals are dependent upon their habitats. However, there is still considerable discussion about what exactly constitutes 'habitat' for fishery species (Langton et al. 1996, Benaka 1999, Beck et al. 2001) and whether or not process-based definitions should be applied. Marine species are often associated with particular nominal habitat types classified according to obvious bottom features such as sediment texture, vegetation type and reef structures (e.g. Greene et al. 1999). Because of obvious habitat-associated abundance patterns there is considerable interest in mapping habitats with the goal of conservation and preservation. 
In 1996, the US Congress acknowledged the serious decline of economically significant species throughout the world and the importance of habitat by amending the Fishery Conservation and Management Act of 1976 to include provisions for identification and conservation of essential fish habitat (EFH) (Schmitten 1999). Implicit in the definition of $\mathrm{EFH}$ is that fish (or invertebrate) abundance and productivity is linked directly to the amount of suitable habitat available. Relationships between habitat quantity and fish abundance or recruitment can rarely be tested with confidence because exact habitat requirements are often poorly known even in well-studied animals (see Gibson 1994). Furthermore, many marine animals shift habitats with season and with age or size so that the relationships between animals and the environment are dynamic through both time and space (Langton et al. 1996, Able 1999, Stoner et al. 2001).

In this review I provide a summary of habitat associations expressed by juvenile queen conch Strombus gigas throughout the Caribbean region, then consider nursery habitat requirements in a broad ecological context through an integration of empirical field and laboratory studies conducted at the Caribbean Marine Research Center over the last 15 yr. While many of the specialized individual findings have been published, new long-term data on conch distribution are presented here, and previously reported research is integrated for spatial context. This includes information on larval delivery systems, habitat choices and direct measures of habitat quality including growth rates and survivorship. I use a comprehensive view of habitat associations and ecological processes to demonstrate that a nursery ground is unique, created by a complex interaction of habitat features and ecological functions.

\section{SUBJECT SPECIES}

The large gastropod mollusc Strombus gigas Linne (queen conch) is one of the most important fishery resource species in the greater Caribbean region (Brownell \& Stevely 1981, Appeldoorn 1994, Stoner 1997a). Geographic range is from Bermuda to south Florida in the United States, and throughout the Bahamas and the Caribbean Sea from Mexico to Venezuela. Queen conch have been harvested for human consumption and for shell products for thousands of years (Doran 1958, Adams 1970, Stoner 1997b). Despite various fishing regulations (Appeldoorn 1994), increasing fishing pressure and habitat loss have reduced populations to the point that the species was listed in Appendix II of the Convention on International Trade in Endangered Species (CITES) in 1992. Species in this category are not currently threat- ened with extinction, but may become so unless trade is subject to strict regulation. The fishery for queen conch was closed entirely in the United States in 1985, and there has been little recovery since that time (Berg \& Glazer 1995, Glazer \& Delgado 2003).

The queen conch has a life cycle typical of the many marine animals with planktonic larvae. Reproduction, involving internal fertilization, occurs for 6 mo during the warmest part of the year (Randall 1964, Weil \& Laughlin 1984, Stoner et al. 1992), and mating is density-dependent (Stoner \& Ray-Culp 2000). The eggs, laid in benthic egg masses, hatch after 3 to $5 \mathrm{~d}$, and the larvae enter the upper water column, where they consume phytoplankton for a period of 2 to $5 \mathrm{wk}$ (Davis et al. 1993, Davis 1998). Larvae ready for metamorphosis settle to the benthos at $\sim 1.0 \mathrm{~mm}$ shell length (D'Asaro 1965, Stoner et al. 1998a), and most conch juveniles occupy clear shallow waters (<10 m depth), consuming diatoms, macroalgae and seagrass detritus (Randall 1964, Stoner \& Waite 1991). Where juveniles are abundant, they live in distinct aggregations (0.2 to 2.0 conch $\mathrm{m}^{-2}$ ) which move slowly over nursery grounds (Stoner \& Ray 1993). With the approach of sexual maturity at 3.5 to 4 yr (Appeldoorn 1998), juveniles migrate to deeper depths (maximum $=35$ to $40 \mathrm{~m}$ ) (Alcolado 1976, Stoner \& Schwarte 1994, Stoner \& Ray 1996a), where they continue herbivory but occupy a variety of bottom types (Randall 1964, Stoner \& Sandt 1992). Growth in shell length ceases at maturity (maximum size $\approx 30 \mathrm{~cm}$ ).

\section{JUVENILE DISTRIBUTION AND BASIC HABITAT ASSOCIATIONS}

\section{Region-wide patterns}

Juvenile queen conch have been observed in a variety of habitat types. Randall (1964) reported that juvenile conch in the Virgin Islands were most abundant in shallow coral-rubble environment, with lower densities on bare sand and in seagrass beds. A similar association was reported from Puerto Rico, with high numbers in coral rubble compared with sand, seagrass and hard bottom (Torres-Rosado 1987). In Florida, juveniles are found in a variety of habitats, including reef rubble, algae-covered hard bottom, and secondarily in mixed beds of algae and seagrass, depending upon general location (Glazer \& Berg 1994, author's pers. obs.). In Cuba (Alcolado 1976), the Turks and Caicos Islands (Hesse 1979), Venezuela (Weil \& Laughlin 1984) and the Bahamas (Stoner et al. 1994, 1996a, this study) juvenile conch are associated primarily with seagrasses (especially turtlegrass Thalassia testudinum), and secondarily with the other habitat types men- 
tioned earlier. Today, the largest production of conch occurs where there are extensive meadows of turtlegrass, but the association is not obligate, and vast expanses of turtlegrass habitat in Cuba, the Turks and Caicos Islands, Venezuela and the Bahamas are unoccupied (author's pers. obs.).

\section{Distribution patterns in the Bahamas}

In the Bahamas and other Caribbean regions with broad shallow-water banks, juvenile queen conch are concentrated in specific locations relatively near the edges of the banks (Stoner et al. 1994). Each summer from 1989 to 1996, a $6 \mathrm{~km}$ wide band along the edge of the Great Bahama Bank near Lee Stocking Island, Exuma Cays, Bahamas ( 50 km²) (Fig. 1), was system- atically surveyed for juvenile conch. Nursery areas were located by towed divers, and aggregations of juveniles were mapped with global positioning systems (GPS) (see Stoner \& Ray 1993, 1996a). Dimensions of the aggregations varied with time, expanding and contracting over the $8 \mathrm{yr}$ survey period (Fig. 2). These aggregations were located within 3 primary nursery areas (Table 1) distinguished by distinct tidal flow fields associated with inlets north and south of Lee Stocking Island. The Tugboat Rock aggregation was small in 1992 and 1996 and disappeared completely in 1991. Juvenile conch were particularly abundant in the Children's Bay Cay nursery, but the areal extent of aggregations varied by 2 orders of magnitude. Changes in aggregation dimensions were not synchronous, except that all were relatively small in 1990 (Table 1). Despite interannual variation in conch num-

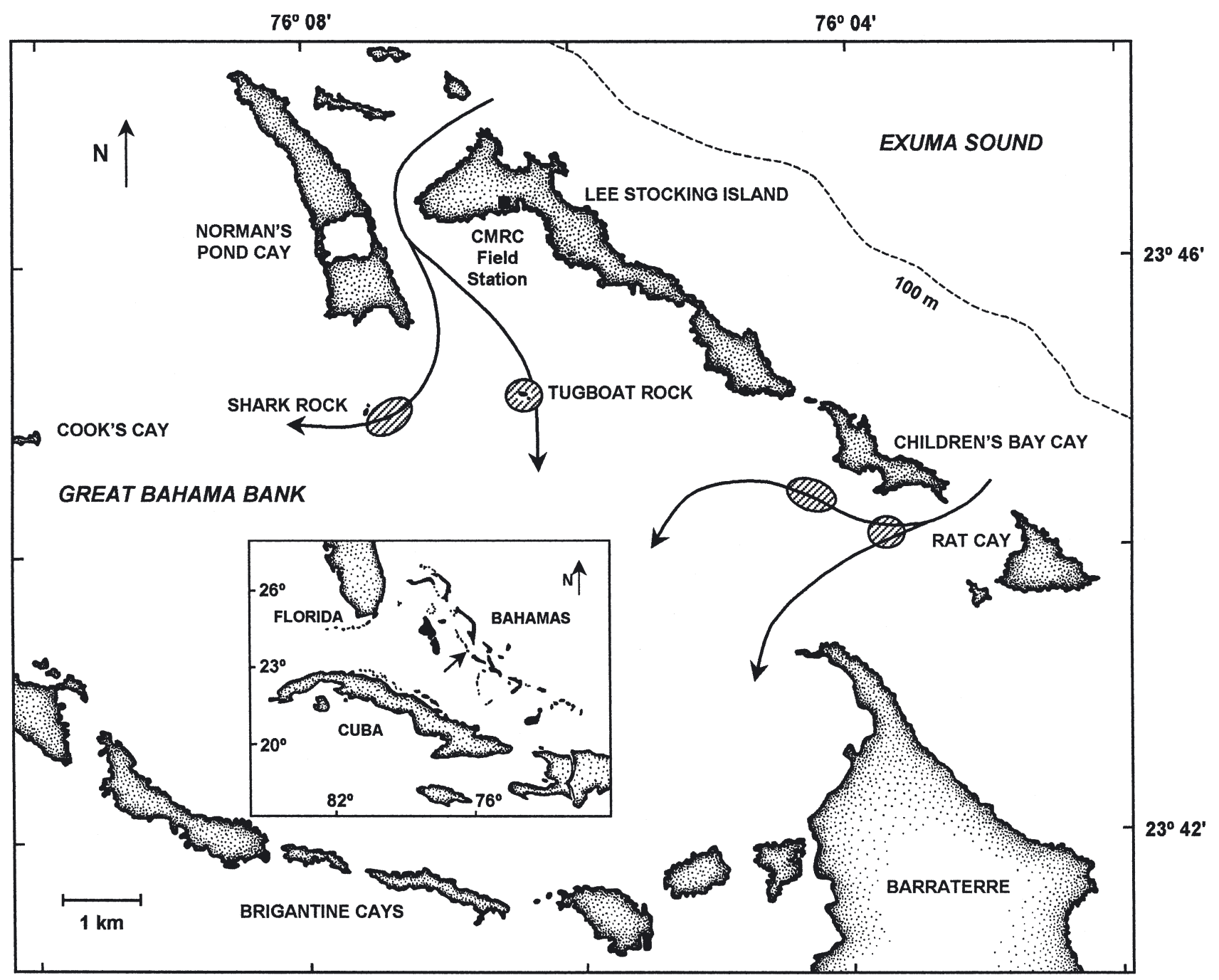

Fig. 1. Area of the Great Bahama Bank near Lee Stocking Island, Exuma Cays, where a long-term investigation of queen conch nurseries was conducted by the Caribbean Marine Research Center. The nurseries, referenced in the text, are located near Shark Rock, Tugboat Rock, and west of Children's Bay Cay (hatched areas). Arrows show the primary axes of flood tidal flow over the bank 
Table 1. Strombus gigas. Summary of juvenile queen conch aggregations at 3 nursery grounds near Lee Stocking Island, Bahamas. Values are the estimated areas of bottom (ha) occupied by juveniles in densities $>0.2 \mathrm{~m}^{-2}$ during summer surveys. The 3 nurseries are Shark Rock (SR), Tugboat Rock (TR), and Children's Bay Cay (CBC) (see Fig. 1). \% is the contribution of the area of each specific nursery to total nursery area in the study site

\begin{tabular}{|lccccccc|}
\hline Year & SR & $\%$ & TR & $\%$ & CBC & $\%$ & Total \\
\hline 1989 & 18.2 & 25 & 13.3 & 18 & 42.6 & 57 & 74.1 \\
1990 & 5.1 & 32 & 4.2 & 26 & 6.6 & 42 & 15.9 \\
1991 & 14.5 & 90 & 0.0 & 0 & 1.7 & 10 & 16.2 \\
1992 & 10.1 & 15 & 1.5 & 2 & 54.3 & 82 & 65.9 \\
1993 & 32.4 & 23 & 12.8 & 9 & 95.1 & 68 & 140.3 \\
1994 & 19.4 & 20 & 24.5 & 26 & 51.3 & 54 & 95.2 \\
1995 & 38.0 & 25 & 77.8 & 51 & 37.2 & 24 & 153.0 \\
1996 & 43.0 & 24 & 6.1 & 3 & 126.9 & 72 & 176.0 \\
Mean & 23 & & 18 & & 52 & & 92 \\
SD & 14 & & 26 & & 42 & & 61 \\
\hline
\end{tabular}

bers in the nursery grounds, high-density aggregations were found in the same general locations year after year, with only scattered individuals in a few other locations. The distribution of shell deposits in the sediment reveals that nursery locations near Lee Stocking Island have been constant for hundreds of years (Stoner \& Ray 1996b).

The majority of queen conch near Lee Stocking Island and in the Bahamas are associated with seagrass meadows. More specifically, juvenile conch in the Shark Rock and Children's Bay Cay nurseries are associated with intermediate densities (608 to 864 shoots $\mathrm{m}^{-2}$ ) of turtlegrass, and field experiments demonstrate that queen conch have a strong preference for that habitat (Stoner \& Waite 1990). However, maps of turtlegrass biomass (correlated closely with shoot density) produced from satellite imagery and ground truth (Armstrong 1993) reveal that the nurs-
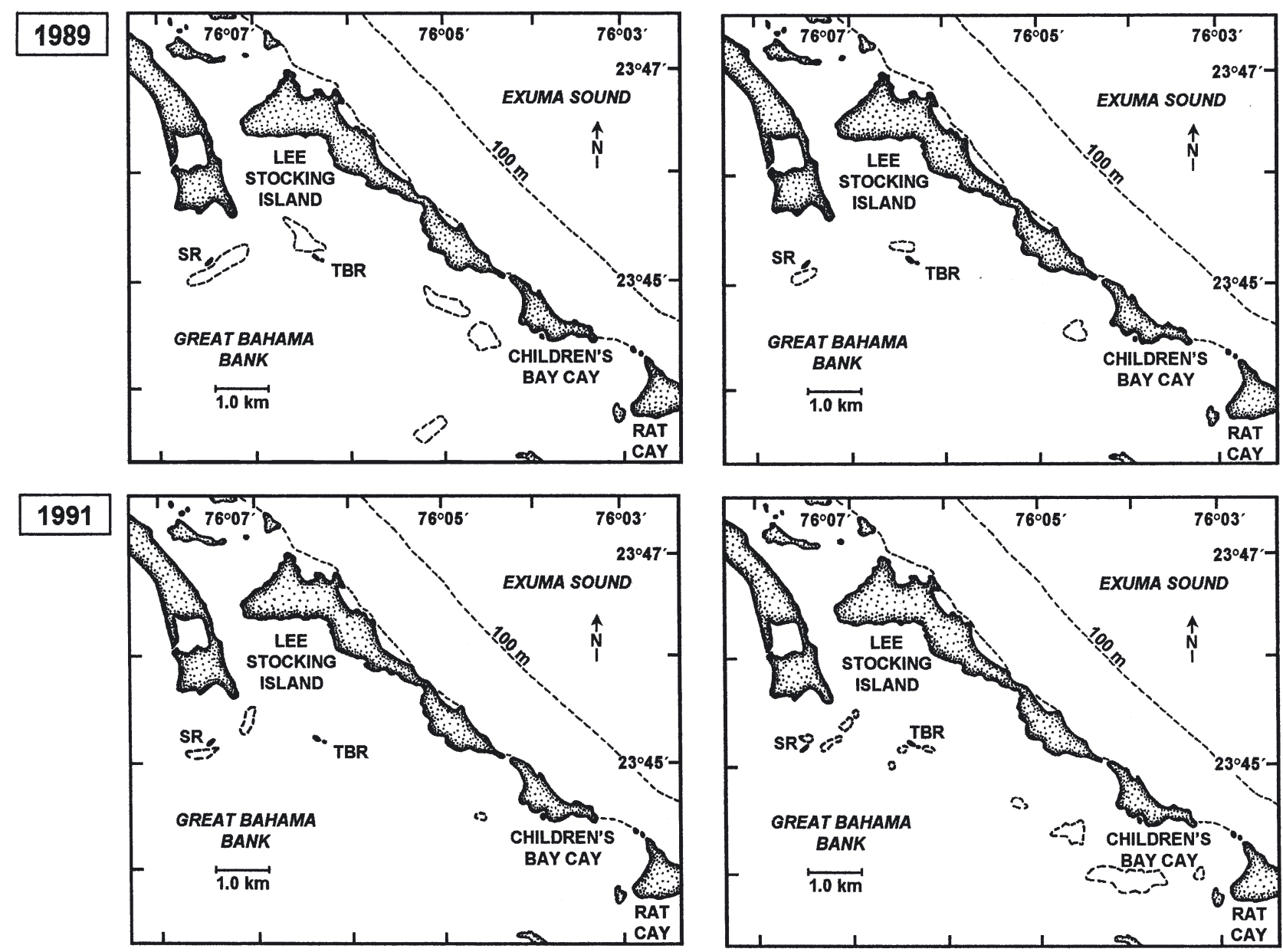

1992

Fig. 2. Strombus gigas. Locations of juvenile queen conch aggregations observed in 8 surveys conducted each summer from 1989 to 1996 near Lee Stocking Island, Bahamas. Boundaries of natural aggregations ( $>0.2$ juveniles $\left.\mathrm{m}^{-2}\right)(\mathrm{dashed}$ lines) were mapped precisely using GPS. Survey methods are described in detail by Stoner \& Ray (1993) 
eries occur in specific locations within vast expanses of turtlegrass, and a large proportion of habitat with preferred turtlegrass density has remained unoccupied for at least a decade. Consequently, maps of seagrass cover hold poor predictive power for conch nursery distribution. When the depth range preferred by juvenile conch (1.5 to $4.0 \mathrm{~m}$ ) was added, ability to predict nursery distribution improved only slightly (Stoner et al. 1996a).

Studies of tidal flow over the Great Bahama Bank showed that conch nurseries lie directly under the primary axes of flood tidal currents over the banks both north and south of Lee Stocking Island (Stoner et al. 1996a). Building on these findings, Jones (1996) used the cool-temperature signature of surface water from the Exuma Sound as an indicator of Sound water as it flowed over the banks during flood tide (Fig. 1). By overlaying spatially comprehensive observations of flood tide waters with known nursery distribution, he observed that conch nurseries were located within areas flushed with the clear, cool water from the
Sound on every flood tide, including neap tides, when tidal excursion onto the bank had lowest areal coverage. Jones (1996) used geographic information systems incorporating seagrass biomass, depth and coverage of flood tidal waters to classify 11000 ha of benthic environment near Lee Stocking Island as either optimal, suitable or unsuitable for juvenile conch (Fig. 3). Of the study area, $79 \%$ was unsuitable and only $6.8 \%$ was optimal. The narrower habitat definition reduced the spatial extent of seagrass meadow previously classified as suitable for juvenile conch, but at least $80 \%$ of the habitat deemed optimal was never occupied in more than $10 \mathrm{yr}$ of surveys and personal observations.

Based upon this combination of surveys and mapping, it is clear that large-scale distribution of queen conch nurseries is dependent upon ecological processes more complex than those reflected in maps of bottom type and depth. Larval delivery systems, food production and shelter from predators are discussed in the sections that follow.
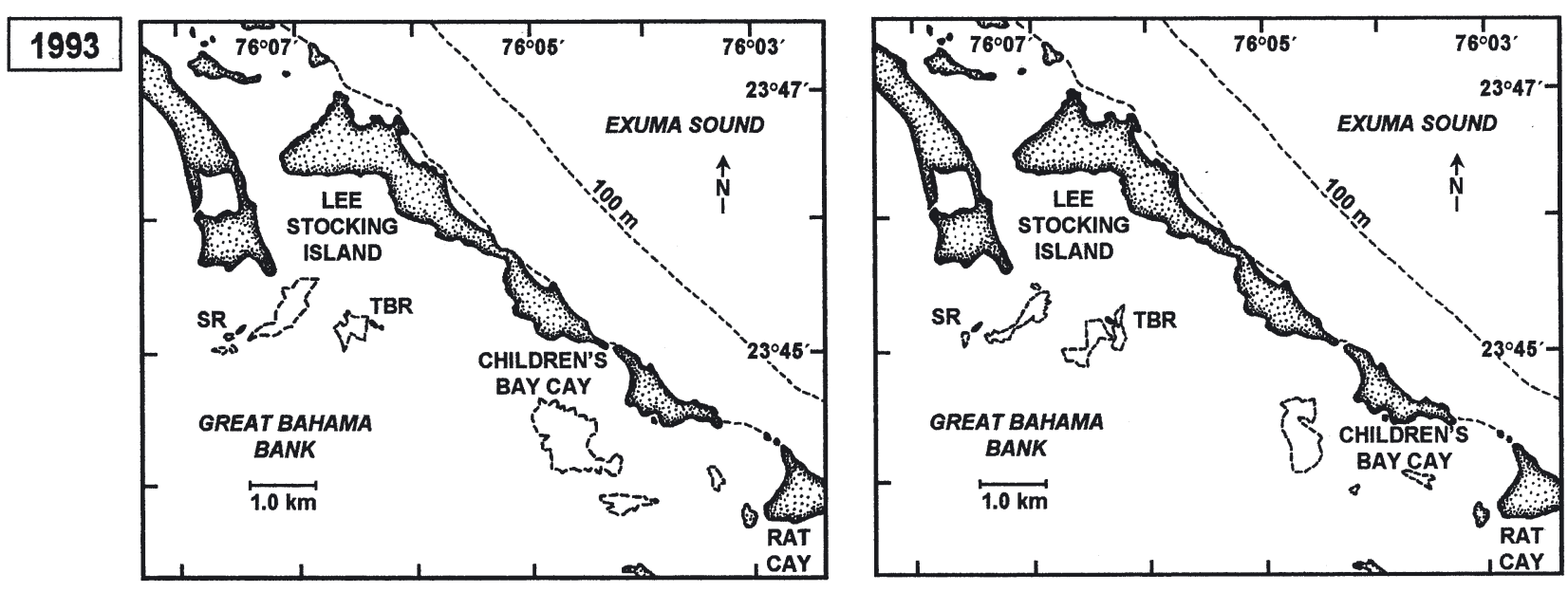

1994

1995
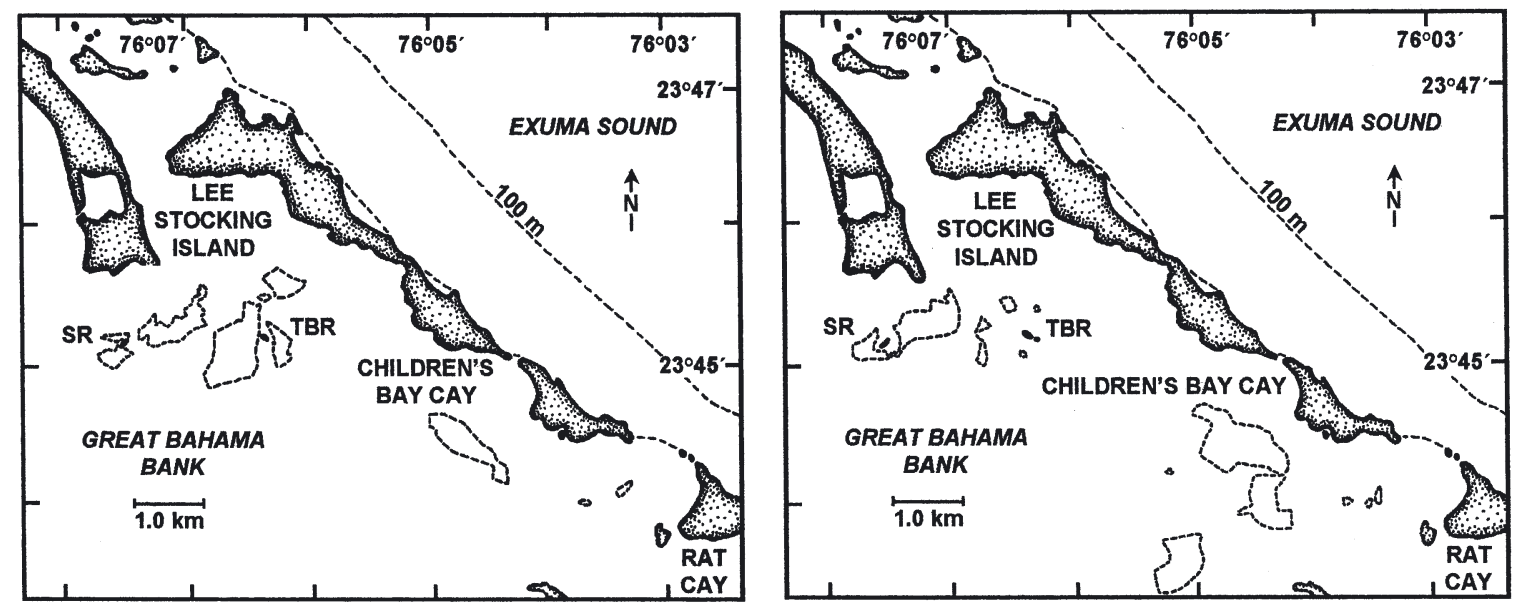

1996

Fig. 2 (continued) 


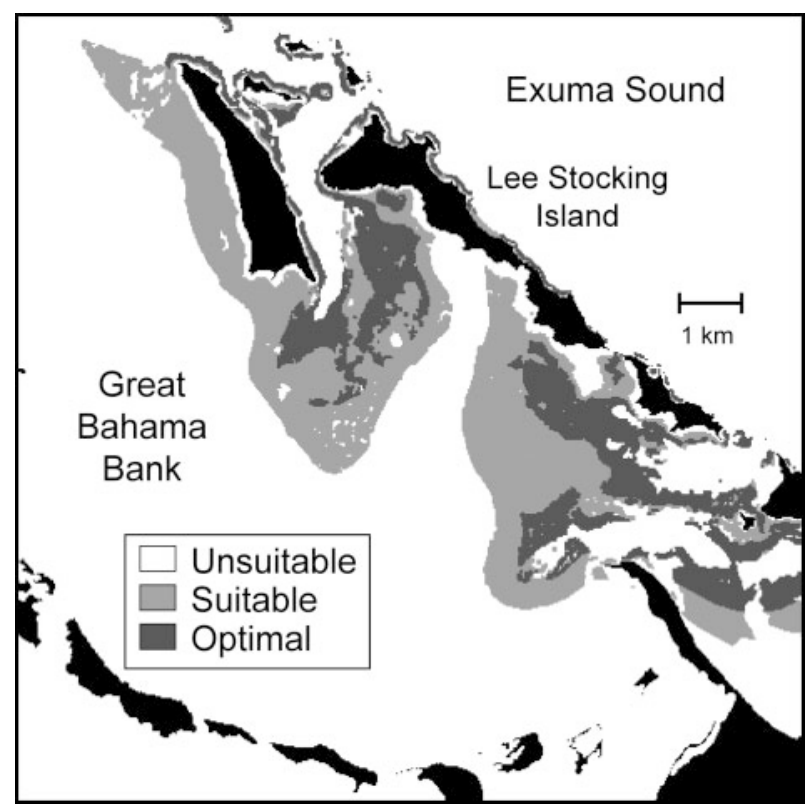

Fig. 3. Strombus gigas. Habitat suitability for juvenile queen conch in the shallow-water environment near Lee Stocking Island, Bahamas. Classification was made based on water depth, seagrass standing crop and the extent to which cool water was carried from Exuma Sound onto the shallow bank on flood tide. The 'suitable' level of suitability was based upon the full range of environmental conditions over which aggregations of juvenile conch were found during seven summer surveys (1989-1995). The 'optimal' level was more restrictive, including conditions where juveniles were found during 4 or more yr. See Jones (1996) for full details

\section{ECOLOGICAL MECHANISMS}

\section{Larval supply and delivery systems}

Since detailed observations near Lee Stocking Island began in the 1980s, most of the queen conch reproductive stock near Lee Stocking Island have occurred on the shallow shelf to the east of the islands primarily in water depths $>10 \mathrm{~m}$, where the adults are beyond the reach of fishers and where mating and egg-laying occur primarily on bare sand (Fig. 1) (Stoner \& Sandt 1992, Stoner \& Ray-Culp 2000). Few juveniles are found east of Exuma Cays, and nursery grounds on the shallow banks west of the islands are the source for the reproductive stock (Stoner \& Schwarte 1994). Newly hatched conch larvae are advected onshore by Ekman processes (Stoner \& Smith 1998), and they are carried onto the Great Bahama Bank with flood tides (Smith \& Stoner 1993) (Fig. 1).

Queen conch larvae were surveyed near Lee Stocking Island between 1988 and 1993 (Stoner \& Davis 1997a). Larvae were directly associated with axes of tidal currents flooding onto the Great Bahama Bank, and concentrations decreased with distance onto the bank within each tidal system. Intensive sampling in the tidal flow field associated with Shark Rock nursery (from the inlet to $10 \mathrm{~km}$ onto the bank) showed that total larval densities as well as densities of metamorphically competent larvae were highest at the center of the nursery ( $\sim \mathrm{km}$ from the inlet). No competent larvae were found at greater distances onto the bank (Fig. 4). Therefore, larval concentration may explain the general occurrence of nursery grounds on the bank in the flood tidal axes (Jones 1996, Stoner \& Davis 1997a) and the lack of juveniles in seagrass habitats further onto the bank. The observation that conch nurseries in the Exuma Cays are virtually all located within 5 to $10 \mathrm{~km}$ from the deep-water edge of the bank (Stoner et al. 1996a) corresponds well with the tidal dispersion of larvae observed near Lee Stocking Island.

Evidence that larval supply has a significant effect on the spatial distribution of queen conch juveniles is provided by significant positive correlations between densities of competent larvae and the size of juvenile populations at 5 nursery sites in the Exuma Cays and

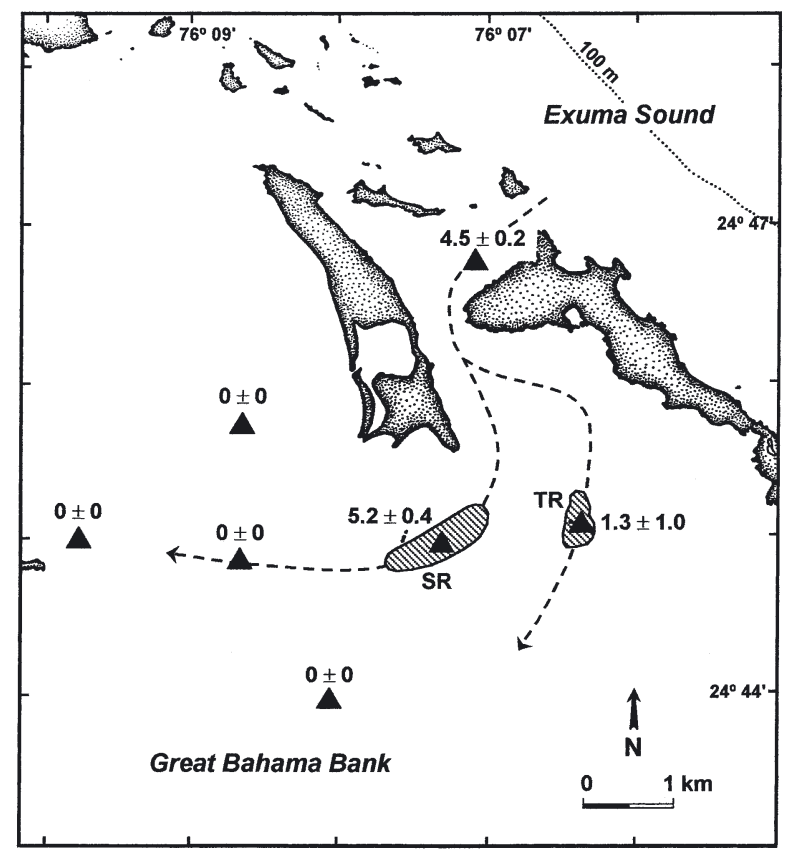

Fig. 4. Strombus gigas. Horizontal distribution of settlementstage queen conch veligers in the tidal flow field that supplies larvae to the Shark Rock (SR) and Tugboat Rock (TR) nursery grounds (hatched areas) west of Lee Stocking Island, Bahamas. The values shown are mean densities (ind. $1000 \mathrm{~m}^{-3}$ ) $( \pm \mathrm{SE})$ during peak reproductive season (July-August) in collections made over the period 1988 to 1993. Arrows show the primary axes of flood tidal flow over the bank. Triangles show the locations where plankton tows were made for veligers 


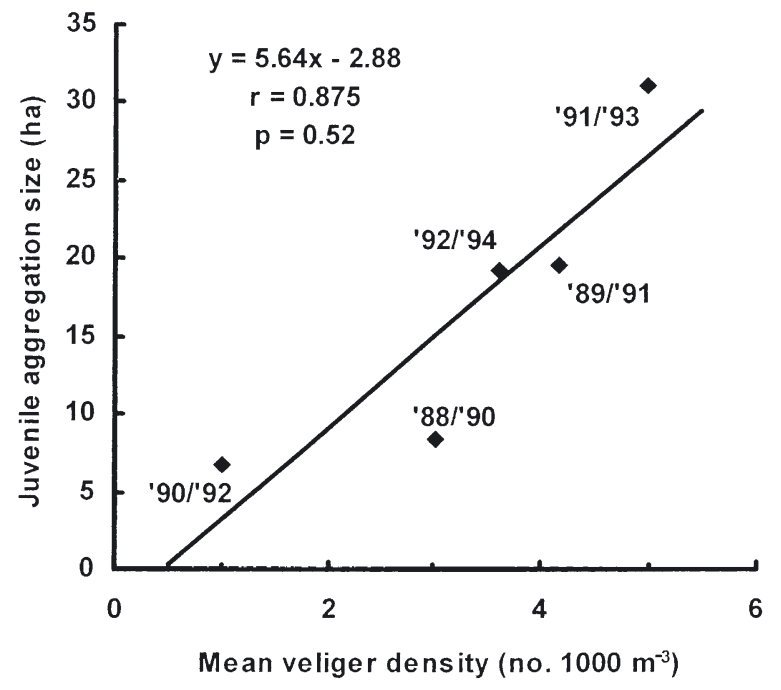

Fig. 5. Strombus gigas. Relationship between queen conch larval abundance and size of the juvenile aggregation at the Shark Rock nursery ground 2 yr later. Each point represents a 2 yr lag between larvae and juveniles because the majority of juveniles in the aggregation each summer were age-2. Values for larval abundance are mean concentrations from all collections made between June and August (typically, n = 12)

4 sites in the Florida Keys (Stoner et al. 1996b). Further support for the importance of larval supply is provided by the fact that interannual variation in the juvenile population size at the Shark Rock nursery is directly correlated with the mean concentration of competent larvae for the year class being considered (Fig. 5).

Recruitment to nursery grounds depends upon a reliable source of metamorphically competent larvae. However, high concentrations of larvae do not guarantee successful recruitment to the benthos. The positive relationship between late-stage larvae and juvenile conch disappears in surveys conducted over spatial scales exceeding hundreds of kilometers in Exuma Sound (Stoner et al. 1998b) and thousands of kilometers when sites in both the Bahamas and Florida are included. Stoner et al. (1996b) concluded that mesoscale and regional differences in juvenile abundance were determined during settlement or in the first year of post-settlement life.

\section{Settlement behavior}

Larvae competent to metamorphose must come into contact with the bottom, undergo metamorphosis and survive the transition to benthic existence to enter the juvenile stage. Queen conch larvae are found primarily in the upper few meters of the water column (Barile et al. 1994, Posada \& Appeldoorn 1994, Stoner \& Davis 1997b). Caribbean-wide occurrence of conch nurseries in shallow subtidal waters (often 1 to $5 \mathrm{~m}$ deep) suggests that competent larvae might depend upon encounters with the bottom for recruitment to the benthos, but there is growing evidence for active process in settlement and metamorphosis. First, conch larvae can delay metamorphosis for $60 \mathrm{~d}$ or more and do so until they encounter a suitable substratum (Noyes 1996, Davis 1998). Second, natural substrata (sediments and seagrass detritus) collected from nursery grounds near Lee Stocking Island elicited a strong response of settlement and metamorphosis in competent conch larvae in the laboratory, while similar materials collected outside the nurseries did not (Fig. 6) (Davis \& Stoner 1994).

Newly settled conch have rarely been collected (Iversen et al. 1987, Sandt \& Stoner 1993), but important insights are gained from an intensive suction dredge study conducted near Lee Stocking Island (Stoner et al. 1998a). Settlement was directly associated with specific locations rather than particular habi-
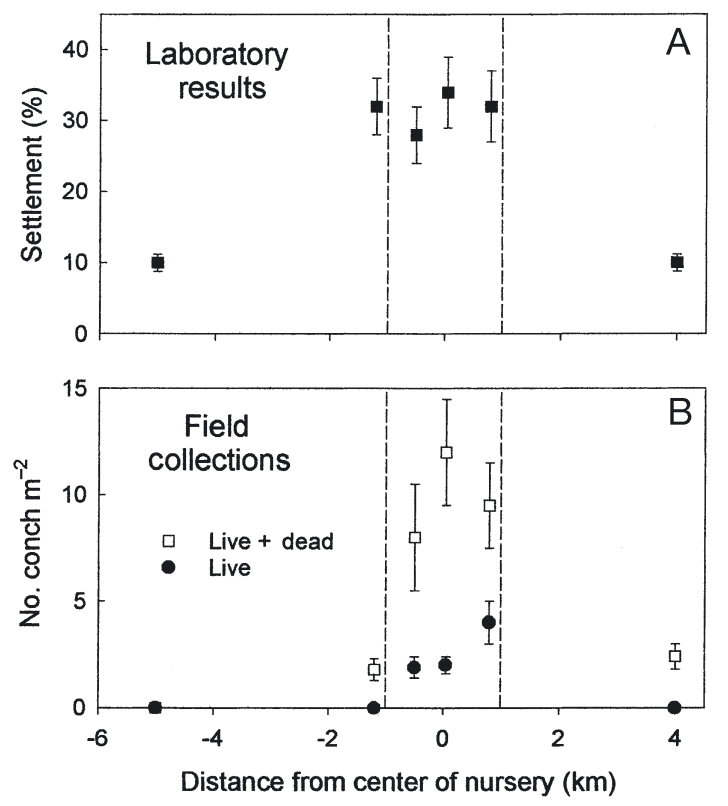

Fig. 6. Strombus gigas. Evidence for spatial variation in queen conch settlement and recruitment on the Great Exuma Bank. The $x$-axis represents a transect through the center of the Shark Rock nursery ground (distance $=0$ ) from the inlet north of Lee Stocking Island (positive values) to a position $5 \mathrm{~km}$ west of the nursery (negative values). (A) The laboratory results are settlement (and metamorphosis) responses by competent conch larvae to seagrass detritus collected at each of the distances shown. (B) Density of age- 0 conch (4 to $40 \mathrm{~mm}$ shell length) in the field determined by suction dredging plotted as a function of distance. Live plus dead conch provides an index of settlement, while density of live conch represents early recruitment. All values are mean $\pm \operatorname{SE}(n=6)$ 

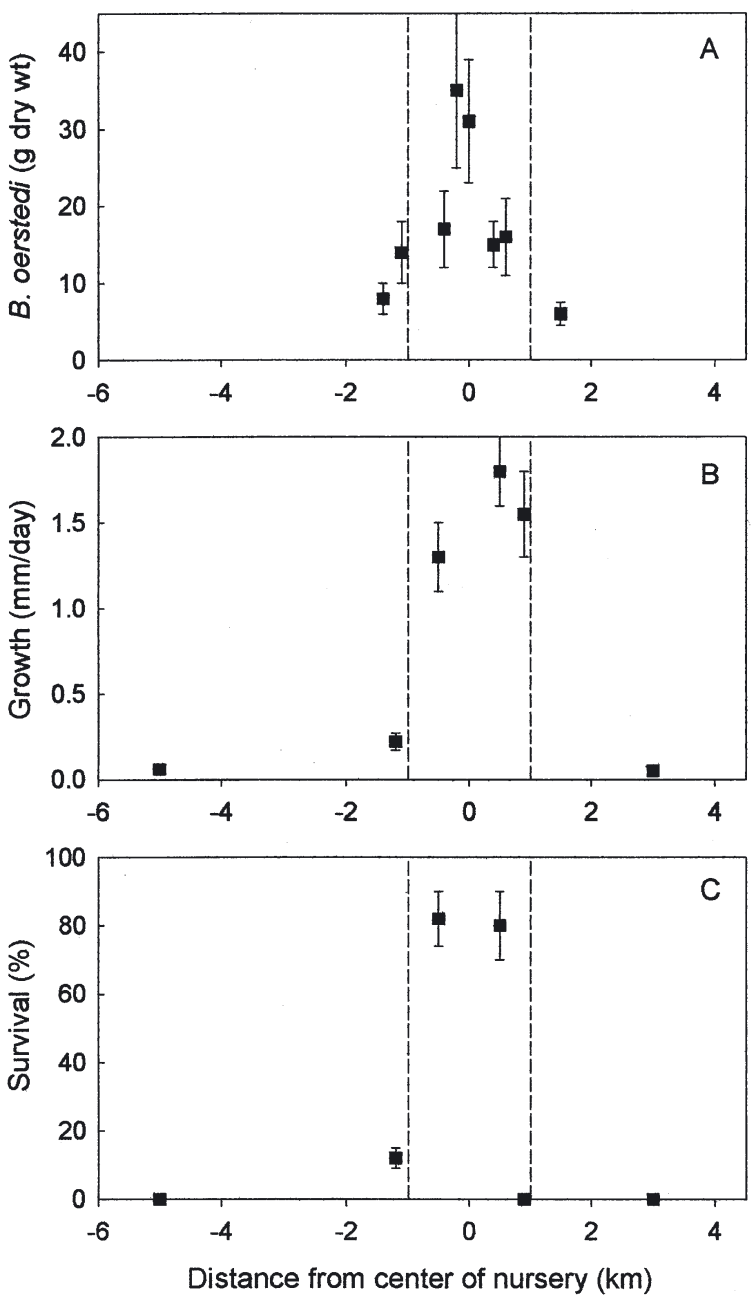

Fig. 7. Strombus gigas. Spatial variation in ecological processes over a transect through the center of the Shark Rock nursery from the inlet north of Lee Stocking Island (positive values) to a position $5 \mathrm{~km}$ west of the nursery (negative values). (A) recruitment of the green alga Batophora oerstedi on coral-rock plates $(15 \times 15 \mathrm{~cm})$ suspended $0.5 \mathrm{~m}$ above the bottom for a period of 3 mo $(n=6)$. (B) growth rates of age-1 conch enclosed in pens at 6 sites along the transect $(n=4)$. (C) Survival rates of age- 1 conch over a 3 mo period $(n=4)$. All values are mean $\pm \mathrm{SE}$

tat types (Fig. 6), and the smallest conch were found in substrata ranging from intertidal sand to dense beds of turtlegrass. Laboratory experiments with a large number of natural substrata revealed that strong metamorphic responses in conch larvae occur on substrata that provide high rates of post-settlement growth (Stoner et al. 1996c); therefore, the locations of historic nursery grounds reflect trophic quality of the environment as well as the characteristics discussed earlier. Over the long term, selective settlement also appears to provide a survival advantage to juvenile queen conch. In the
Shark Rock nursery there is a close positive correlation between settlement rate and survivorship for the first several months of post-settlement life (Stoner et al. 1998a). After recruitment to the benthos queen conch continue to make habitat-related choices that affect fitness of the juveniles through mechanisms associated with both growth and survival.

\section{Nutrition and growth}

Queen conch juveniles are ideal subjects for in situ studies of growth because they are herbivorous and can be held in specific locations with low-sided and topless pens that have few cage-related artifacts (Stoner 1994). To test the hypothesis that growth in conch can be predicted from benthic habitat type, individually marked age-1 conch were monitored for growth at 2 historically important nursery grounds and at 6 sites without juvenile conch (Stoner \& Sandt 1991). Comparable sites were chosen on the basis of similarity in depth, seagrass cover, and sediment grain size and organic content. The highest growth rate at a nonconch site was just $40 \%$ of that found in nursery sites, and there was zero growth over $45 \mathrm{~d}$ at the 3 other nonconch sites. It is clear, therefore, that the variables chosen were not adequate to predict growth.

We now know that growth in juvenile conch depends upon the productivity of the red and green macroalgae that serve as food, and this productivity is highly variable over the bank environment (Stoner et al. 1994, 1995a). Maximum growth of macroalgae on settlement plates protected from conch grazing occurred in the center of nursery grounds in each of 2 tidal flow fields west of Lee Stocking Island (Fig. 7A). The mechanisms for this spatial variation in algae remain unknown, but conch settlement (Davis \& Stoner 1994), growth and survival (Stoner et al. 1996c) all follow a pattern similar to algal recruitment (Fig. 7B,C).

Habitats providing for high growth in juvenile conch can extend beyond the traditional nursery grounds. Transplants of age- 1 juveniles at 2 different nurseries, using both free-ranging individuals (Stoner \& Ray 1993) and enclosures (Ray \& Stoner 1994), show that growth rates outside nurseries (to a distance of $1 \mathrm{~km}$ ) are sometimes equal to or greater than rates inside the nurseries. This indicates that nutritionally suitable habitats are not fully saturated with juvenile conch. Instead, population size is probably limited by the supply of settlers, as implied by the correlation between late-stage larvae and subsequent juvenile abundance (Fig. 5). Also, growth is known to be inversely densitydependent in queen conch (Stoner 1989, Stoner \& Ray 1993, Stoner \& Davis 1994) because of the grazing pressures that they exert on preferred foods (Stoner et 
al. 1995b). However, per capita mortality rates are also inversely density-dependent in juvenile conch, and juveniles often move about in high-density aggregations within suitable nursery grounds (Ray \& Stoner 1994, Stoner \& Lally 1994).

Stoner et al. (1994) observed that persistent longterm locations for juvenile conch on the Great Bahama Bank occurred where shallow sand bars $(<1 \mathrm{~m})$ are adjacent to turtlegrass beds. Because the smallest juveniles are often found in bare sand or rubble environment rather than in seagrass (Iversen et al. 1987, Sandt \& Stoner 1993), it has been hypothesized that settlement occurs on the shallow, bare substrata, where foods in the form of sediment-dwelling diatoms are abundant. Subsequent experiments conducted on a fine scale within nursery grounds (Ray \& Stoner 1995) revealed that growth rates of $5 \mathrm{~mm}$ conch in sand were equivalent to those in adjacent seagrass, but slightly larger juveniles (11 and $22 \mathrm{~mm}$ ) had significantly higher growth rates (and survival; see below) in seagrass. It remains unknown whether the observed size-related shift in juvenile conch away from sand habitat results from ontogenetic migration or differential mortality.

\section{Shelter and predation processes}

Predation on juvenile queen conch has been studied intensively over the last $20 \mathrm{yr}$ because of interest in enhancing and rehabilitating natural populations through releases of hatchery-reared juveniles (Dalton 1994, Iversen \& Jory 1997, Stoner \& Glazer 1998). Predators have been identified and numerous field and laboratory experiments have been conducted with age- 0 , age- 1 and age- 2 juveniles ( 1 to $>150 \mathrm{~mm}$ shell length) to determine size-specific mortality, the role of shell morphology, habitat structure, location and density dependence (Ray et al. 1994, Stoner 1997a, Stoner \& Glazer 1998, Ray-Culp et al. 1999). Emphasis here is placed on spatial variation in juvenile mortality.

Laboratory and field experiments show that juvenile conch of all sizes have strong preferences for habitats with above-ground structure (Stoner \& Waite 1990, Sandt \& Stoner 1993, Ray \& Stoner 1995, Ray-Culp et al. 1999), and field experiments with juveniles ranging between 5 and $80 \mathrm{~mm}$ indicate that the relationship between seagrass density and conch survivorship is dome-shaped, with maximum survival at $~ 600$ shoots $\mathrm{m}^{-2}$ (Marshall 1992, Ray \& Stoner 1994, 1995). While the mechanisms for this function are unknown, conch nursery grounds are often associated with seagrass meadows with intermediate shoot density.

Survivorship of juvenile conch within a seagrass meadow is strongly influenced by location, as is true for growth. To test for large-scale variation in growth and mortality, Stoner \& Sandt (1991) transplanted age1 conch to 8 sites over the Great Bahama Bank. Survivorship was high in 2 historically important nursery sites and low at all others. Similar results occurred on a finer scale when survivorship was tracked for juvenile conch immediately inside and outside conch aggregations (Marshall 1992, Stoner \& Ray 1993), despite high growth rates outside the aggregations. When sediments in and around a conch nursery near Lee Stocking Island were collected by suction dredge and sorted for the smallest post-settlement conch (both living and recently killed), Stoner et al. (1998a) were able to determine that only conch settling inside the traditional nursery survived (Figs. 6 \& 7). Analysis of predator distribution, numerical responses of predators to conch density and controlled field experiments will be needed to understand the interactions between conch density and spatial patterns of survivorship.

\section{DISCUSSION}

\section{Habitat form vs habitat function}

Traditionally, habitats for benthic marine animals have been defined on the basis of easily measured features such as depth, temperature and bottom type. However, as observed for queen conch, a demersal species may occupy a variety of bottom types over its geographic range, and large areas of seemingly appropriate bottom may never be occupied. Other recent descriptive studies in both marine and estuarine systems illustrate the limited utility of simple bottom-type classification schemes for predicting animal distributions. For example, Bell et al. (1988) reported that density of fishes in seagrass beds was related to location, analogous to our findings with conch. Large differences in abundance patterns of fishes and macroinvertebrates among seagrass meadows in Texas and Louisiana were related to salinity, wave energy, amount of edge and landscape context (Minello 1999). Similarly, abundance patterns of fishes in Bonaire were strongly affected by location, water transparency, amount of physical exposure and the structural complexity of the biotope, particularly in mangroves and seagrasses (Nagelkerken et al. 2000). Recent investigations in 5 different bottom types in each of 3 estuaries in New Jersey and Connecticut revealed that patterns of abundance (Goldberg et al. 2002) and growth (Phelan et al. 2000) in juvenile winter flounder Pseudopleuronectes americanus were not predictable on the basis of nominal habitat type, and differences among the habitats were not consistent across the estuaries or over 2 yr. Others have reported variation in fauna asso- 
ciated with salt marshes related to elevation, extent of inundation and proximity to open water and other habitats (Rozas \& Reed 1993, McIvor \& Rozas 1996, Irlandi \& Crawford 1997, Minello \& Webb 1997, Kneib 2000). It is clear that hydrographic and landscape context has a large influence on habitat associations (Irlandi et al. 1995, Peterson et al. 2001, Minello \& Rozas 2002), perhaps as much as the substratum itself. Mechanisms of habitat utilization are complicated by the fact that many marine species are dispersed as planktonic larvae. The presence of juvenile conch is fundamentally dependent upon a supply of settlementstage larvae, which is related to the location of larval sources and water circulation. Successful settlement of larvae is also critical and depends upon biochemical cues associated with microscopic foods, and these cues have localized distribution. There is increasing awareness that centers of settlement and/or recruitment exist within large, seemingly homogeneous habitats. This is now apparent for queen conch, and there are recent examples for fishes. Booth et al. (2000) observed that spatial patterns of recruitment in damselfishes in One Tree Island lagoon (Australia) were persistent over 3 yr and that certain 'recruitment hotspots' on the reef were affected by local topography and oceanography. Similarly, centers of winter flounder settlement were attributed to larval retention mechanisms and size-related shifts in habitat preference (Stoner et al. 2001, Manderson et al. 2003). Recruitment limitation, which can occur over both temporal and spatial scales, has been reported for a variety of molluscs (Peterson \& Summerson 1992, Peterson et al. 1996, Stoner et al. 1996b, this study) and fishes (Doherty \& Fowler 1994, Armsworth 2002).

Descriptive and experimental studies show clearly that nursery grounds for queen conch are defined, in part, by patterns of food production in the form of benthic algae, as speculated by Weil \& Laughlin (1984) and Martín-Mora et al. (1995). Similarly, Jenkins \& Hamer (2001) found that the uneven distribution of King George whiting Sillaginodes punctata over seagrass beds in southern Australia was determined more by patterns of prey than seagrass density. Prey abundance was also one of several statistically significant components in distribution models for age-0 winter flounder in a New Jersey estuary (Stoner et al. 2001). Growth can be a sensitive indicator of food quality at a site, and growth in transplanted animals has been used as a metric for habitat quality for a variety of marine fishes (Cowan et al. 1992, Sogard 1992, Rooker \& Holt 1997, Phelan et al. 2000), queen conch (Martín-Mora et al. 1995, Ray \& Stoner 1995) and other invertebrates (Mintz et al. 1994, DeMontaudouin 1996). Several of these studies have shown that growth is not readily predicted from benthic habitat classification.
Mortality is a standard component of traditional population and fishery models, and numerous field (Wilson et al. 1987, Barbeau et al. 1994, Heck \& Coen 1995, Lipcius et al. 1998, Nemeth 1998, Rooker et al. 1998, 1999, Stoner \& Glazer 1998, Irlandi et al. 1999, Paperno et al. 2000) and laboratory (Tupper \& Boutilier 1995, 1997, Lindholm et al. 1999, Ray-Culp et al. 1999, Manderson et al. 2000) experiments have demonstrated the importance of different habitat types and/or habitat complexity for the survival of fishery species. While variation in mortality within habitat types has rarely been considered as a component of habitat or distribution models, recent investigations show that survival of various economically significant invertebrates in seagrass meadows varies with habitat location, patch size, and the types and abundance of predators foraging in specific locations (Peterson 1986, Bologna \& Heck 1999, Hovel \& Lipcius 2001, Peterson et al. 2001, this study). Furthermore, differential predation can determine whether specific locations serve as recruitment sources or sinks (Lipcius et al. 1997, Peterson et al. 2001). It is now clear that predator abundance and efficiency are critical elements of nursery habitat quality that vary over space (and time), even within habitats having homogeneous general appearance.

Modeling habitat suitability is attractive because, in principle, the models for a particular species should be applicable across systems and could be valuable in predicting potential effects of habitat loss. However, because of the limitations in our knowledge of habitat quality and function, and because habitat qualities may be site-specific, as apparent for queen conch, there have been relatively few demonstrations of a positive relationship between habitat quantity and abundance of marine fishery species. For example, Rijnsdorp et al. (1992) found a direct positive relationship between nursery habitat area and recruitment level of Solea solea in the North Sea, English Channel, Bristol Channel and Irish Sea. Also, Cobb et al. (1999) used knowledge of microhabitat requirements for juvenile American lobster Homarus americanus to calculate habitat-related losses associated with an oil spill. Attempts to correlate habitat availability with abundance patterns in Caribbean spiny lobster Panulirus argus have not yet been successful (Herrnkind et al. 1997). As with queen conch, this may be related to spatially variable predation and survival, which is not directly predictable on the basis of bottom type (Lipcius et al. 1997). To date, most habitat suitability models for aquatic organisms incorporate only obvious environmental parameters, such as bottom type, depth, temperature and salinity, and not the more complex variables that affect larval delivery, settlement, growth and mortality. For queen conch, functional nursery habitat was determined by the spatial-temporal inter- 
section of these processes, none of which were predictable on the basis of benthic classification.

An operational definition of functional habitat for juvenile queen conch is relatively simple, because they have low mobility and no major shifts in behavior (apart from burial intensity) during the first 2 to 3 yr of benthic life. They live in stenohaline conditions and are herbivorous throughout the demersal stage. Most non-molluscan species important to fisheries have more dramatic habitat shifts with size, more mobility and longer migrations; consequently, their habitat models will be more complicated. Also, habitat models for animals occupying temperate and estuarine locations may be more complex than that for queen conch because of large temporal variation in temperature, salinity, plant cover, and predator and prey fields, but the concept of functional habitat remains the same.

\section{Habitat management}

There is rising awareness among fishery managers (Langton \& Auster 1999, Fluharty 2000, Beck et al. 2001) and the fishing community (Gutting 1999) that critically important habitats exist for many exploited species and that habitats (perhaps ecosystems) need to be managed along with traditional population approaches to fisheries management. Because of some obvious associations between certain taxa and traditional habitat classifications, it is tempting to begin habitat management for demersal species by mapping bottom types. Mapping is now done routinely for some shallow marine and estuarine environments with combinations of remote sensing, photo interpretation, geographic information systems and computerized algorithms for habitat classification. Mapping is intuitively appealing and may be a good beginning, but simply mapping bottom types can present a potential trap.

Fisheries-related habitat management involves conservation, restoration and mitigation related to system functions that are crucial to the sustainability of economically significant species at all life stages. In these terms, maps of bottom type have certain limitations that need to be recognized by those using them as management tools. Demersal species often depend upon more than one kind of bottom type over their life history (e.g. nurseries, adult feeding grounds, spawning habitats), certain life stages may occupy a variety of bottom types, and large areas of seemingly appropriate bottom may never be occupied. All of these potential pitfalls are evident in the life history of queen conch and other species.

In conservation, it is critical to identify and protect important sites on the basis of their ecological function and not just general appearance. Obvious places war- ranting special protection are spawning sites and historically important nurseries. Successful conservation will depend upon a good understanding of the habitat requirements for target species, selecting locations which may have historical importance for a species, and protecting enough of the crucial habitat for the desired level of fishery yield. In the absence of detailed information needed for habitat-related fisheries management (Langton et al. 1996), some authors have proposed general protection of structurally complex environments such as reefs, sponge beds, cobble bottom and seagrass beds (Auster et al. 1997, Auster \& Langton 1999). The rationale for this conclusion is 2 -fold. First, complex habitats, especially those created by biogenic structures, tend to shelter high numbers of fish and invertebrates and their prey. Second, complex habitats and animals having obligate habitat associations may be most susceptible to disturbance. However, it may be exceedingly difficult to protect all of a certain general habitat form, so a good knowledge of the most important sites or locations could be crucial.

Restoration of habitat valuable to fisheries will require that habitat functions be re-established and not just their form. Recent results indicate that salt marshes can be restored or created to provide critical functions for fishes if natural hydrologic features are maintained (Minello \& Webb 1997, Dionne et al. 1999, Williams \& Zedler 1999). Good progress is also being made in freshwater wetlands (Gaff et al. 2000) and mangroves (Vose \& Bell 1994, Imbert et al. 2000). However, the need for better assessment of functions related to feeding, growth, residence time and trends in overall community structure has been mentioned by virtually all of those working to restore wetlands. Physical conditions make subtidal habitats more difficult to restore and evaluate for function than intertidal or wetland habitats. We still know relatively little about recovery rates in the continental-shelf environment (Auster \& Langton 1999), and recovery can be very slow in some cases. For example, Brown-Peterson et al. (1993) found that differences in species richness, species composition, abundance and length-frequency patterns in fishes between restored and reference seagrass sites could persist for 3 decades.

The concerns are similar in cases of habitat mitigation. A working habitat must not be sacrificed for a replacement that does not have equivalent function despite seemingly correct appearance. The risk is particularly acute in cases where there are centers of recruitment determined by circulation and larval supply systems, or where there are other location effects that enhance growth or survival. Without site-specific information on essential habitat functions, it will be difficult to predict whether or not a mitigation action will have the intended effect of offsetting other losses. 
'Habitat' is more abstract than generally considered, and accurate definition will need to include the combination of dynamic features and ecological processes that provide a functional space for subject species. For this reason, habitat is more difficult to assess than the relatively direct measurements for animal populations, and management of habitat for fisheries species will necessitate broader ecological understanding and more information than traditional approaches to population dynamics. In the absence of detailed ecological information, habitat management will need to proceed cautiously to prevent irreversible damage to marine environment and populations by human activities. Establishment of marine protected areas and preservation of environments known to be particularly sensitive to impact may be the most practical approach to habitat management given the general paucity of robust habitat models for fishery species. The transition from traditional population management to habitat-based fisheries management involves a major change in thinking about the role of habitat protection, the role of biodiversity, and precautionary approach (Bodansky 1991, Ludwig et al. 1993, Clark 1996, Hilborn 1997, Fluharty 2000). The change will not be easy, but such a change is crucial with ever increasing direct and indirect impacts of the human population on marine environment.

Acknowledgements. This research was supported by the Caribbean Marine Research Center, the Perry Institute of Marine Science (formerly the Perry Foundation), the Shearwater Foundation, and many years of funding from the National Undersea Research Program of NOAA (US Department of Commerce). Special thanks to M. Ray-Culp, N. Mehta, M. Davis, and B. Bower-Dennis, who worked with the field program during this long-term investigation. Important collaborations also occurred with R. Armstrong, D. Hanisak, N. P. Smith and P. Pitts. I thank W. Head, R. Jones, K. Schwarte, J. Waite, E. Wishinski, the staff at Lee Stocking Island, and numerous students and volunteers for their help in the field. B. Bower-Dennis drafted the maps used in this paper, and M. Spencer assisted with the final graphics. R. Wicklund and B. Olla promoted and guided the research throughout its duration. J. Manderson, M. Ray-Culp, C. H. Peterson and anonymous reviewers provided helpful criticism of the manuscript.

\section{LITERATURE CITED}

Able KW (1999) Measures of juvenile fish habitat quality: examples from a National Estuarine Research Reserve. In: Benaka L (ed) Fish habitat: essential fish habitat and rehabilitation. American Fisheries Society, Symposium 22, Bethesda, MD, p 134-147

Adams JE (1970) Conch fishing industry of Union Island, Grenadines, West Indies. J Trop Sci 12:279-288

Alcolado PM (1976) Crecimiento, variaciones morfológicas de la concha y algunos datos biológicos del cobo Strombus gigas L. (Mollusca, Mesogastrópoda). Acad Cienc Cuba Inst Oceanol 34:1-36
Appeldoorn RS (1988) Age determination, growth, mortality and age of first reproduction in adult queen conch, Strombus gigas L., off Puerto Rico. Fish Res 6:363-378

Appledoorn RS (1994) Queen conch management and research: status, needs and priorities. In: Appledoorn RS, Rodriquez B (eds) Queen conch biology, fisheries and mariculture. Fundacion Científica Los Roques, Caracas, p 301-319

Armstrong RA (1993) Remote sensing of submerged vegetation canopies for biomass estimation. Int J Remote Sensing 14:621-627

Armsworth PR (2002) Recruitment limitation, population regulation, and larval connectivity in reef fish metapopulations. Ecology 83:1092-1104

Auster PJ, Langton RW (1999) The effects of fishing on fish habitat. In: Benaka L (ed) Fish habitat essential fish habitat and rehabilitation. American Fisheries Society, Symposium 22, Bethesda, MD, p 150-187

Auster PJ, Watling L, Rieser A (1997) Comment: the interface between fisheries research and habitat management. N Am J Fish Manage 17:591-595

Barbeau MA, Scheibling RE, Hatcher BG, Taylor LH, Hennigar AW (1994) Survival analysis of tethered juvenile sea scallops Placopecten magellanicus in field experiments: effects of predators, scallop size and density, site and season. Mar Ecol Prog Ser 115:243-256

Barile PJ, Stoner AW, Young CM (1994) Phototaxis and vertical migration of the queen conch (Strombus gigas Linne) veliger larvae. J Exp Mar Biol Ecol 183:147-162

Beck MW, Heck KL, Able KW, Childers DL, Eggleston DB and 8 others (2001) The identification, conservation, and management of estuarine and marine nurseries for fish and invertebrates. Bioscience 51:633-641

Bell JD, Steffe AS, Westoby M (1988) Location of seagrass beds in estuaries: effects on associated fish and decapods. J Exp Mar Biol Ecol 122:127-146

Benaka L (ed) (1999) Fish habitat: essential fish habitat and rehabilitation. American Fisheries Society, Symposium 22, Bethesda, MD

Berg CJ Jr, Glazer RA (1995) Stock assessment of a large marine gastropod (Strombus gigas) using randomized and stratified towed-diver censusing. ICES Mar Sci Symp 199: 247-258

Bodansky D (1991) Scientific uncertainty and the precautionary principle. Environment 33:41-44

Bologna PAX, Heck KL (1999) Differential predation and growth rates of bay scallops within a seagrass habitat. J Exp Mar Biol Ecol 239:299-314

Booth DJ, Kingsford MJ, Doherty PJ, Beretta GA (2000) Recruitment of damselfishes in One Tree Island lagoon: persistent interannual spatial patterns. Mar Ecol Prog Ser 202:219-230

Brown-Peterson NJ, Peterson MS, Rydene DA, Eames RW (1993) Fish assemblages in natural versus well-established recolonized seagrass meadows. Estuaries 16:177-189

Brownell WN, Stevely JM (1981) The biology, fisheries, and management of the queen conch, Strombus gigas. Mar Fish Rev 43:1-12

Clark C (1996) Marine reserves and the precautionary management of fisheries. Ecol Appl 6:369-370

Cobb JS, Clancy M, Wahle RA (1999) Habitat-based assessment of lobster abundance: a case study of an oil spill. In: Benaka L (ed) Fish habitat essential fish habitat and rehabilitation. American Fisheries Society, Symposium 22, Bethesda, MD, p 285-298

Cowan JH, Birdsong RS, Houde ED, Priest JS, Sharp WC, Mateja GB (1992) Enclosure experiments on survival and 
growth of black drum eggs and larvae in lower Chesapeake Bay. Estuaries 15:392-402

D'Asaro CN (1965) Organogenesis, development and metamorphosis in the queen conch, Strombus gigas, with notes on the breeding habits. Bull Mar Sci 15:359-416

Dalton A (1994) Mariculture of the queen conch (Strombus gigas L.): development of nursery and growout techniques. In: Appeldoorn RS, Rodriquez B (eds) Queen conch biology, fisheries, and mariculture. Fundacion Científica Los Roques, Caracas, p 253-260

Davis M (1998) The effects of natural foods, temperature and salinity on the length of larval life for the tropical gastropod Strombus gigas. PhD thesis, Florida Institute of Technology, Melbourne

Davis M, Stoner AW (1994) Trophic cues induce metamorphosis of queen conch larvae (Strombus gigas Linnaeus). J Exp Mar Biol Ecol 180:83-102

Davis M, Bolton CA, Stoner AW (1993) A comparison of larval development, growth, and shell morphology in three Caribbean Strombus species. Veliger 36:236-244

DeMontaudouin X (1996) Factors involved in growth plasticity of cockles Cerastoderma edule (L.), identified by field survey and transplant experiments. J Sea Res 36: 251-265

Dionne M, Short FT, Burdick DM (1999) Fish utilization of restored, created, and reference salt-marsh habitat in the Gulf of Maine. In: Benaka L (ed) Fish habitat essential fish habitat and rehabilitation. American Fisheries Society, Symposium 22, Bethesda, MD, p 384-404

Doherty P, Fowler T (1994) An empirical test of recruitment limitation in a coral reef fish. Science 263:935-939

Doran E Jr (1958) The Caicos conch trade. Geogr Rev 48: $388-401$

Fluharty D (2000) Habitat protection, ecological issues, and implementation of the Sustainable Fisheries Act. Ecol Appl 10:325-337

Gaff H, DeAngelis DL, Gross LJ, Salinas R, Shorrosh M (2000) A dynamic landscape model for fish in the Everglades and its application to restoration. Ecol Model 127:33-52

Gibson RN (1994) Impact of habitat quality and quantity on the recruitment of juvenile flatfishes. Neth J Sea Res 32: 191-206

Glazer RA, Berg CJ Jr (1994) Queen conch research in Florida: an overview. In: Appledoorn RS, Rodriquez B (eds) Queen conch biology, fisheries and mariculture. Fundacion Científica Los Roques, Caracas, p 79-95

Glazer RA, Delgado GA (2003) Towards a holistic strategy to managing Florida's queen conch (Strombus gigas) population. Proc Gulf Carib Fish Inst 55 (in press)

Goldberg R, Phelan B, Pereira J, Hagan S, Clark P, Bejda A, Calabrese A, Studholme A, Able KW (2002) Variability in habitat use by young-of-the-year winter flounder, Pseudopleuronectes americanus, in three northeastern U.S. estuaries. Estuaries 25:215-226

Greene HG, Yoklavich MM, Starr RM, O'Connell VM, Wakefield WW, Sullivan DE, McRea JE Jr, Cailliet GM (1999) A classification scheme for deep seafloor habitats. Oceanol Acta 22:663-678

Gutting RE Jr (1999) conserving fish habitat from the seafood perspective. In: Benaka L (ed) Fish habitat: essential fish habitat and rehabilitation. American Fisheries Society, Symposium 22, Bethesda, MD, p 23-30

Heck KL, Coen LD (1995) Predation and the abundance of juvenile blue crabs: a comparison of selected east and gulf coast (USA) studies. Bull Mar Sci 57:877-883

Herrnkind WF, Butler MJ, Hunt JH, Childress M (1997) Role of physical refugia: implications from a mass sponge die-off in a lobster nursery in Florida. Mar Freshw Res 48: 759-769

Hesse KO (1979) Movement and migration of the queen conch, Strombus gigas in the Turks and Caicos Islands. Bull Mar Sci 29:303-311

Hilborn R (1997) Uncertainty, risk, and the precautionary principle. In: Pikitch EL, Huppert DD, Sissenwine MP (eds) Global trends: fisheries management. American Fisheries Society, Symposium 20, Bethesda, MD, p 100-106

Hovel KA, Lipcius RN (2001) Habitat fragmentation in a seagrass landscape: patch size and complexity control blue crab survival. Ecology 82:1814-1829

Imbert D, Rousteau A, Scherrer P (2000) Ecology of mangrove growth and recovery in the Lesser Antilles: state of knowledge and basis for restoration projects. Restor Ecol 8:230-236

Irlandi EA, Crawford MK (1997) Habitat linkages: the effect of intertidal saltmarshes and adjacent subtidal habitats on abundance, movement, and growth of an estuarine fish. Oecologia 110:222-230

Irlandi EA, Ambrose WG, Orlando BA (1995) Landscape ecology and the marine environment: how spatial configuration of seagrass habitat influences growth and survival of the bay scallop. Oikos 72:307-313

Irlandi EA, Orlando BA, Ambrose WG (1999) Influence of seagrass habitat patch size on growth and survival of juvenile bay scallops, Argopecten irradians concentricus (Say). J Exp Mar Biol Ecol 235:21-43

Iversen ES, Jory DE (1997) Mariculture and enhancement of wild populations of queen conch (Strombus gigas) in the western Atlantic. Bull Mar Sci 60:929-941

Iversen ES, Rutherford ES, Bannerot SP, Jory DE (1987) Biological data on Berry Islands (Bahamas) queen conchs, Strombus gigas, with mariculture and fisheries management implications. Fish Bull 85:299-310

Jenkins GP, Hamer PA (2001) Spatial variation in the use of seagrass and unvegetated habitats by post-settlement King George whiting (Percoidei: Sillaginidae) in relation to meiofaunal distribution and macrophyte structure. Mar Ecol Prog Ser 224:219-229

Jones RL (1996) Spatial analysis of biological and physical features associated with the distribution of queen conch, Strombus gigas, nursery habitats. MS thesis, Florida Institute of Technology, Melbourne

Kneib RT (2000) Salt marsh ecoscapes and production transfers by estuarine nekton in the southeastern United States. In: Weinstein MP, Kreeger DA (eds) Concepts and controversies in tidal march ecology. Kluwer, Dordrecht, p 267-291

Langton RW, Auster PJ (1999) Marine fishery and habitat interactions: to what extent are fisheries and habitat interdependent? Fisheries 24:14-21

Langton RW, Steneck RS, Gotceitas V, Juanes F, Lawton P (1996) The interface between fisheries research and habitat management. N Am J Fish Manage 16:1-7

Lindholm JB, Auster PJ, Kaufman LS (1999) Habitat-mediated survivorship of juvenile (0-year) Atlantic cod Gadus morhua. Mar Ecol Prog Ser 180:247-255

Lipcius RN, Stockhausen WT, Eggleston DB, Marshall LS, Hickey B (1997) Hydrodynamic decoupling of recruitment, habitat quality and adult abundance in the Caribbean spiny lobster: source-sink dynamics? Mar Freshw Res 48:807-815

Lipcius RN, Eggleston DB, Miller DL, Luhrs TC (1998) The habitat-survival function for Caribbean spiny lobster: an inverted size effect and non-linearity in mixed algal and seagrass habitats. Mar Freshw Res 49:807-816 
Ludwig D, Hilborn R, Walters C (1993) Uncertainty, resource exploitation, and conservation: lessons from history. Science 260:17-18

Manderson JP, Phelan BA, Stoner AW, Hilbert J (2000) Predator-prey relations between age-1+ summer flounder (Paralichthys dentatus, Linnaeus) and age-0 winter flounder (Pseudopleuronectes americanus, Walbaum): predator diets, prey selection, and effects of sediments and macrophytes. J Exp Mar Biol Ecol 251:17-39

Manderson JP, Pessutti J, Meise C, Johnson D, Shaheen P (2003) Winter flounder settlement dynamics and the modification of settlement patterns by post-settlement processes in a NW Atlantic estuary. Mar Ecol Prog Ser 253: 253-267

Marshall LS Jr (1992) Survival of juvenile queen conch, Strombus gigas, in natural habitats: impact of prey, predator and habitat features. PhD thesis, College of William and Mary, Williamsburg

Martín-Mora E, James FC, Stoner AW (1995) Developmental plasticity in the shell of the queen conch Strombus gigas. Ecology 76:981-994

McIvor C, Rozas LP (1996) Direct nekton use of intertidal salt marsh habitat and linkage with adjacent habitats: a review from the southeastern United States. In: Nordstrom KF, Roman CT (eds) Estuarine shores: evolution, environments and human alterations. John Wiley, New York, p 311-334

Minello TJ (1999) Nekton densities in shallow estuarine habitats of Texas and Louisiana and the identification of essential fish habitat. In: Benaka L (ed) Fish habitat essential fish habitat and rehabilitation. American Fisheries Society, Symposium 22, Bethesda, MD, p 43-75

Minello TJ, Rozas LP (2002) Nekton in Gulf Coast wetlands: fine-scale distributions, landscape patterns, and restoration implications. Ecol Appl 12:441-455

Minello TJ, Webb JW Jr (1997) Use of natural and created Spartina alternifora salt marshes by fishery species and other aquatic fauna in Galveston Bay, Texas, USA. Mar Ecol Prog Ser 151:165-179

Mintz JD, Lipcius RN, Eggleston DB, Seebo MS (1994) Survival of juvenile Caribbean spiny lobster-effects of shelter size, geographic location and conspecific abundance. Mar Ecol Prog Ser 112:255-266

Nagelkerken I, Dorenbosch M, Verberk WCEP, Cocheret de la Morinière E, van der Velde G (2000) Importance of shallow-water biotopes of a Caribbean bay for juvenile coral reef fishes: patterns in biotope association, community structure and spatial distribution. Mar Ecol Prog Ser 202: 175-192

Nemeth RS (1998) The effect of natural variation in substrate architecture on the survival of juvenile bicolor damselfish. Environ Biol Fishes 53:129-141

Noyes KH (1996) Ontogeny of settlement behavior in queen conch (Strombus gigas) larvae. MS thesis, Florida Institute of Technology, Melbourne

Paperno R, Targett TE, Grecay PA (2000) Spatial and temporal variation in recent growth, overall growth, and mortality of juvenile weakfish (Cynoscion regalis) in Delaware Bay. Estuaries 23:10-20

Peterson CH (1986) Enhancement of Mercenaria mercenaria densities in seagrass beds: is pattern fixed during settlement season or altered by subsequent differential survival? Limnol Oceanogr 31:200-205

Peterson CH, Summerson HC (1992) Basin-scale coherence of population dynamics of an exploited marine invertebrate, the bay scallop: implications of recruitment limitation. Mar Ecol Prog Ser 90:257-272
Peterson CH, Summerson HC, Luettich RA (1996) Response of bay scallops to spawner transplants: a test of recruitment limitation. Mar Ecol Prog Ser 132:93-107

Peterson CH, Fodrie FJ, Summerson HC, Powers SP (2001) Site-specific and density-dependent extinction of prey by schooling rays: generation of a population sink in topquality habitat for bay scallops. Oecologia 129:349-356

Phelan BA, Goldberg R, Bejda AJ, Pereira J and 5 others (2000) Estuarine and habitat-related differences in growth rates of young-of-the-year winter flounder (Pseudopleuronectes americanus) and tautog (Tautoga onitis) in three northeastern US estuaries. J Exp Mar Biol Ecol 247:1-28

Posada J, Appeldoorn RA (1994) Preliminary observations on the distribution of Strombus larvae in the eastern Caribbean. In: Appledoorn RS, Rodriguez B (eds) Queen conch biology, fisheries and mariculture. Fundacion Científica Los Roques, Caracas, p 191-199

Randall JE (1964) Contributions to the biology of the queen conch, Strombus gigas. Bull Mar Sci Gulf Carib 14: 246-295

Ray M, Stoner AW (1994) Experimental analysis of growth and survivorship in a marine gastropod aggregationbalancing growth with safety in numbers. Mar Ecol Prog Ser 105:47-59

Ray M, Stoner AW (1995) Growth, survivorship, and habitat choice in a newly settled seagrass gastropod, Strombus gigas. Mar Ecol Prog Ser 123:83-94

Ray M, Stoner AW, O'Connell SM (1994) Size-specific predation of juvenile queen conch Strombus gigas: implications for stock enhancement. Aquaculture 128:79-88

Ray-Culp M, Davis M, Stoner AW (1999) Predation by xanthid crabs on early post-settlement gastropods: the role of prey size, prey density, and habitat complexity. J Exp Mar Biol Ecol 240:303-321

Rijnsdorp AD, Van Beek FA, Flatman S, Millner RM, Riley JD, Giret M, DeClerck R (1992) Recruitment of sole stocks, Solea solea (L.), in the northeast Atlantic. Neth J Sea Res 29:173-192

Rooker JR, Holt SA (1997) Utilization of subtropical seagrass meadows by newly settled red drum Sciaenops ocellatus: patterns of distribution and growth. Mar Ecol Prog Ser 158:139-149

Rooker JR, Holt GJ, Holt SA (1998) Vulnerability of newly settled red drum (Sciaenops ocellatus) to predatory fish: is early-life survival enhanced by seagrass meadows? Mar Biol 131:145-151

Rooker JR, Holt SA, Holt GJ, Fuiman LA (1999) Spatial and temporal variability in growth, mortality, and recruitment potential of postsettlement red drum, Sciaenops ocellatus, in a subtropical estuary. Fish Bull 97:581-590

Rozas LP, Reed DJ (1993) Nekton use of marsh-surface habitats in Louisiana (USA) deltaic salt marshes undergoing submergence. Mar Ecol Prog Ser 1993:147-157

Sandt VJ, Stoner AW (1993) Ontogenetic shift in habitat by early juvenile queen conch, Strombus gigas-patterns and potential mechanisms. Fish Bull 91:516-525

Schmitten RA (1999) Essential fish habitat: opportunities and challenges for the next millennium. In: Benaka L (ed) Fish habitat essential fish habitat and rehabilitation. American Fisheries Society, Symposium 22, Bethesda, Maryland, p 3-10

Smith NP, Stoner AW (1993) Computer simulation of larval transport through tidal channels - role of vertical migration. Estuar Coast Shelf Sci 37:43-58

Sogard SM (1992) Variability in growth rates of juvenile fishes in different estuarine habitats. Mar Ecol Prog Ser 85: 35-53 
Stoner AW (1989) Density-dependent growth and the grazing effects of juvenile queen conch (Strombus gigas L.) in a tropical seagrass meadow. J Exp Mar Biol Ecol 130: $119-127$

Stoner AW (1994) Significance of habitat and stock pretesting for enhancement of natural fisheries: experimental analyses with queen conch Strombus gigas. J World Aquacult Soc 25:155-165

Stoner AW (1997a) The status of queen conch (Strombus gigas) research in the Caribbean. Mar Fish Rev 59:14-22

Stoner AW (1997b) Shell middens as indicators of long-term distributional pattern in Strombus gigas, a heavily exploited marine gastropod. Bull Mar Sci 61:559-570

Stoner AW, Davis M (1994) Experimental outplanting of juvenile queen conch, Strombus gigas: comparison of wild and hatchery-reared stocks. Fish Bull 92:390-411

Stoner AW, Davis M (1997a) Abundance and distribution of queen conch veligers (Strombus gigas Linne) in the central Bahamas. 1. Horizontal patterns in relation to reproductive and nursery grounds. J Shellfish Res 16:7-18

Stoner AW, Davis M (1997b) Abundance and distribution of queen conch veligers (Strombus gigas Linne) in the central Bahamas. 2. Vertical patterns in nearshore and deepwater habitats. J Shellfish Res 16:19-29

Stoner AW, Glazer RA (1998) Variation in natural mortality: implications for queen conch stock enhancement. Bull Mar Sci 62:427-442

Stoner AW, Lally W (1994) High-density aggregation in queen conch, Strombus gigas: formation, patterns, and ecological significance. Mar Ecol Prog Ser 106:73-84

Stoner AW, Ray M (1993) Aggregation dynamics in juvenile queen conch (Strombus gigas): population structure, mortality, growth, and migration. Mar Biol 116:571-582

Stoner AW, Ray M (1996a) Queen conch, Strombus gigas, in fished and unfished locations of the Bahamas: effects of a marine fishery reserve on adults, juveniles and larval production. Fish Bull 94:551-565

Stoner AW, Ray M (1996b) Shell remains provide clues to historical distribution and abundance patterns in a large seagrass-associated gastropod (Strombus gigas). Mar Ecol Prog Ser 135:101-108

Stoner AW, Ray-Culp M (2000) Evidence for Allee effects in an over-harvested marine gastropod: density-dependent mating and egg production. Mar Ecol Prog Ser 202: 297-302

Stoner AW, Sandt VJ (1991) Experimental analysis of habitat quality for juvenile queen conch in seagrass meadows. Fish Bull 89:693-700

Stoner AW, Sandt VJ (1992) Population structure and seasonal movements of queen conch, Strombus gigas, in deep-water habitats of the Bahamas. Bull Mar Sci 51: $287-300$

Stoner AW, Schwarte KC (1994) Queen conch, Strombus gigas, reproductive stocks in the central Bahamas: distribution and probable sources. Fish Bull 92:171-179

Stoner AW, Smith NP (1998) Across-shelf transport of gastropod larvae in the central Bahamas: rapid responses to local wind conditions. J Plankton Res 20:1-16

Stoner AW, Waite JM (1990) Distribution and behavior of queen conch, Strombus gigas, relative to seagrass standing crop. Fish Bull 88:573-585

Stoner AW, Waite JM (1991) Trophic biology of Strombus gigas in nursery habitats: diets and primary food sources in seagrass meadows. J Mollusc Stud 57:451-460

Stoner AW, Sandt VJ, Boidron-Metairon IF (1992) Seasonality

Editorial responsibility: Charles Peterson (Contributing Editor), Morehead City, North Carolina, USA of reproductive activity and abundance of veligers in queen conch, Strombus gigas. Fish Bull 90:161-170

Stoner AW, Hanisak MD, Smith NP, Armstrong RA (1994) Large-scale distribution of queen conch nursery habitats: implications for stock enhancement. In: Appledoorn RS, Rodriguez B (eds) Queen conch biology, fisheries and mariculture. Fundacion Científica Los Roques, Caracas, p 169-189

Stoner AW, Lin J, Hanisak MD (1995a) Relationships between seagrass bed characteristics and juvenile queen conch (Strombus gigas Linne) abundance in the Bahamas. J Shellfish Res 14:315-323

Stoner AW, Ray M, Waite JM (1995b) Effects of a large herbivorous gastropod on macrofauna communities in tropical seagrass meadows. Mar Ecol Prog Ser 121:125-137

Stoner AW, Pitts PA, Armstrong RA (1996a) The interaction of physical and biological factors in the large-scale distribution of juvenile queen conch in seagrass meadows. Bull Mar Sci 58:217-233

Stoner AW, Glazer RA, Barile PJ (1996b) Larval supply to queen conch nurseries: relationships with recruitment process and population size in Florida and the Bahamas. J Shellfish Res 15:407-420

Stoner AW, Ray M, Glazer RA, McCarthy KJ (1996c) Metamorphic responses to natural substrata in a gastropod larva: decisions related to postlarval growth and habitat preference. J Exp Mar Biol Ecol 205:229-243

Stoner AW, Ray-Culp M, O'Connell SM (1998a) Settlement and recruitment of queen conch, Strombus gigas, in seagrass meadows: associations with habitat and micropredators. Fish Bull 96:885-899

Stoner AW, Mehta N, Ray-Culp M (1998b) Mesoscale distribution patterns of queen conch (Strombus gigas linne) in Exuma Sound, Bahamas: links in recruitment from larvae to fishery yields. J Shellfish Res 17:955-969

Stoner AW, Manderson JP, Pessutti JP (2001) Spatially explicit analysis of estuarine habitat for juvenile winter flounder: combining generalized additive models and geographic information systems. Mar Ecol Progr Ser 213:253-271

Torres-Rosado ZA (1987) Distribution of two mesogastropods, the queen conch, Strombus gigas Linnaeus, and the milk conch, Strombus costatus Gmelin, in La Parguera, Lajas, Puerto Rico. MS thesis, University of Puerto Rico, Mayagüez

Tupper M, Boutilier RG (1995) Effects of habitat on settlement, growth, and postsettlement survival of Atlantic cod (Gadus morhua). Can J Fish Aqua Sci 52:1834-1841

Tupper M, Boutilier RG (1997) Effects of habitat on settlement, growth, predation risk and survival of a temperate reef fish. Mar Ecol Prog Ser 151:225-236

Vose FE, Bell SS (1994) Resident fishes and macrobenthos in mangrove-rimmed habitats-evaluation of habitat restoration by hydrologic modification. Estuaries 17: 585-596

Weil ME, Laughlin GR (1984) Biology, population dynamics, and reproduction of the queen conch, Strombus gigas Linne, in the Archipielago de Los Roques National Park. J Shellfish Res 4:45-62

Williams GD, Zedler JB (1999) Fish assemblage composition in constructed and natural tidal marshes of San Diego Bay: relative influence of channel morphology and restoration history. Estuaries 22:702-716

Wilson KA, Heck KL Jr, Able KW (1987) Juvenile blue crab, Callinectes sapidus, survival: an evaluation of eelgrass, Zostera marina, as refuge. Fish Bull 85:53-58

Submitted: February 1, 2002; Accepted: May 6, 2003

Proofs received from author(s): July 17, 2003 